\title{
ОМЕНТОПЕКСИЯ ПРИ ХИРУРГИЧЕСКОМ ЛЕЧЕНИИ АСЕПТИЧЕСКОГО ПАНКРЕАТИТА
}

\author{
(C) Сигал 3.М., Бабушкин Ф.Г.
}

\author{
Кафедра оперативной хирургии и топографической анатомии \\ Ижевской государственной медицинской академии, Ижевск, Удмуртская Республика \\ E-mail: sigalzoltan@yandex.ru
}

\begin{abstract}
Цель работы: повысить эффективность хирургического лечения больных с панкреонекрозом за счет улучшения кровоснабжения тканей поджелудочной железы и печени сосудами большого сальника. В эксперименте производилось моделирование острого панкреатита путем введения аутожелчи в ткань поджелудочной железы у животных. В большом сальнике выявили участки с наилучшим кровоснабжением и сатурацией сосудов не менее 90-97\%. Амплитуда пульсовых осцилляций (АПО) поджелудочной железы в среднем составила 2,0 \pm 0,3 мм. Через трое суток у животных проявлялась клиника острого панкреатита. Некротические участки поджелудочной железы, определенные интраоперационной пульсографией, были удалены. Большой сальник рассекали на две неравные части ближе к левому краю. Поджелудочную железу покрывали левым краем большого сальника. Оставшуюся часть сальника накладывали на печень. После окутывания поджелудочной железы левым краем большого сальника АПО в среднем составила $1,2 \pm$ 0,2 мм. Данный способ апробировали в клинике.
\end{abstract}

Ключевые слова: большой сальник, сатурация, пульсография.

\section{OMENTOPEXY IN SURGICAL MANAGEMENT OF ASEPTIC PANCREONECROSIS Sigal Z.M., Babushkin F.G.}

Topographic Anatomy and Operative Surgery Department of Izhevsk State Medical Academy, Izhevsk, Udmurt Republic

The study was aimed at increasing effectiveness of surgical treatment of patients with pancreonecrosis through improving blood supply of pancreatic and hepatic tissues with the vessels of the greater omentum. During the experiment acute pancreatitis was modelled in animals by injecting their bile into pancreatic tissue. The areas of the best blood supply and vessels saturation of at least $90-97 \%$ were revealed in the greater omentum. Amplitude of pulse oscillations (APO) of the pancreas averaged $2.0 \pm 0.3 \mathrm{~mm} .3$ days later clinical manifestations of acute pancreatitis were revealed in the animals. Necrotic areas of the pancreas determined by intraoperative pulsography were removed. The greater omentum was dissected into two unequal parts closer to the left margin. The pancreas was covered with the left margin of the greater omentum. The remaining part of the greater omentum was placed on the liver. After wrapping the pancreas in the left margin of the greater omentum APO averaged $1.2 \pm 0.2 \mathrm{~mm}$. This method was used at clinics while treating people.

Keywords: intraoperational hemodynamic monitoring, aseptic pancreonecrosis, greater omentum.

Распространение в последние десятилетия объема оперативных вмешательств во всех отраслях хирургии с применением пластики потребовало поиски универсального аутологичного материала. Накопленный опыт показал, что всем требованиям, предъявляемым такому материалу, отвечает большой сальник. При этом для профилактики осложнений необходимо объективно определять нарушения жизнеспособности органов и тканей.

Отмечается, что сальник отличается обилием фибробластов, клеток кровеносных сосудов, эндотелия, гистиоцитов, тучных и плазматических клеток, а также специфических образований, так называемых «млечных пятен», представляющих собой миниатюрные лимфатические узлы. Благодаря уникальным анатомо-физиологическим свойствам сальник обладает иммунокомпетентностью, адгезивностью, пластичностью, гемостатичностью, возможностью абсорбции и большой поверхностью, что делает его идеальным материа- лом для устранения косметических и функциональных дефектов, заполнения мертвых пространств, улучшения питания и образования органных анастомозов в оперированных органах.

Одной из причин неблагоприятного заживления тканей является нарушение локальной гемодинамики, что приводит к нарушению регенерации тканей. Несмотря на богатую васкуляризацию большого сальника, которая отмечается в ряде работ, нами методом пульсографии по 3.М. Сигалу (1998) обнаружены неоднородные показатели локальной гемодинамики в различных его отделах.

Как показали наши исследования, наилучшая локальная гемодинамика обнаружена в левом и нижнем отделах большого сальника, наихудшая в среднем отделе. В качестве критериев удовлетворительного кровоснабжения сальника служат наиболее высокие показатели амплитуды пульсовых осцилляций (АПО). В эксперименте они колебались от 2,2 до 3,3 мм, тогда как 
показатели АПО в участках с редуцированным кровоснабжением сальника составили от 0,8 до 1,5 мм.

Острый панкреатит - одна из важнейших проблем экстренной хирургии. Актуальность ее обусловлена прежде всего заметным увеличением числа больных с острым панкреатитом. В настоящее время она занимает 3-е место среди острых хирургических заболеваний органов брюшной полости и составляет около $12,5 \%$ от всей острой патологии [3, 12]. Летальность при стерильном панкреонекрозе регистрируется в 20-30 случаях, при инфицированном достигает $40-70 \%[2,4,5,6]$. В связи с этим выбор тактики лечения острого панкреатита продолжает оставаться одной из наиболее значимых задач [1].

Ряд авторов является сторонниками активной хирургической тактики и при стерильном панкреонекрозе $[10,14]$ с летальностью $3,5 \%$.

Применяемые в последние годы широкие оментобурсостомы не лишены недостатков. По мнению ряда авторов, ведущим в патогенезе острого панкреатита является нарушение микроциркуляции в поджелудочной железе, что ведет к нарастанию гипоксии и ацидоза с формированием ацинарного некроза [8].

До настоящего времени отсутствует единый алгоритм дооперационной диагностики стерильного и инфицированного некроза поджелудочной железы, в связи с чем нередко выполняются ошибочные хирургические вмешательства при асептическом панкреонекрозе [7, 11].

Оптимальные сроки хирургического вмешательства при панкреонекрозе до сих пор не определены. С одной стороны операции, отсроченные до 3-4 недель, выполняются в условиях хорошей демаркации нежизнеспособности ткани. С другой - вызванная сепсисом органная недостаточность нередко наблюдается раньше времени демаркации, делая такую задержку операции опасной [15].

\section{МАТЕРИАЛЫ И МЕТОДЫ ИССЛЕДОВАНИЯ}

Острый панкреатит воспроизводился путем введения аутожелчи из расчета 0,2 мл на 1 кг веса в ткань поджелудочной железы с помощью инъекции у 10 животных (кролики). Способ осуществлялся следующим образом: под местной анестезией sol. Novocaini $0,25 \%$ раствором производилась верхняя срединная лапаротомия.
Проводили гемодинамические измерения в большом сальнике, выявляли участки с наилучшим кровоснабжением (на пульсограмме $1 / 3$ левого края большого сальника амплитуда пульсовых осцилляций должна быть 3,0 мм и более) и сатурацией сосудов большого сальника не менее 90-97\%. После вскрытия сальниковой сумки определяли гемодинамику здоровой поджелудочной железы по методу 3.М. Сигала. Из желчного пузыря откачивалась желчь и вводилась в ткань поджелудочной железы, в результате чего железа окрашивалась в интенсивно желтый цвет. Брюшная полость ушивалась наглухо.

Через 3-е суток у животных проявлялись клинические признаки острого панкреатита (похудание, гиподинамия, отсутствие аппетита, вздутие живота, повышение температуры тела, лейкоцитоз, повышение сахара в крови). На этом сроке была произведена релапаротомия, при которой обнаружилось неравномерное вздутие петель кишечника; в брюшной полости выражен спаечный процесс, геморрагический процесс; поджелудочная железа отечная, гиперемированная, на поджелудочной железе и большом сальнике располагались стеариновые бляшки. Производилась пульсография поджелудочной железы на фоне острого панкреатита.

Некротические участки поджелудочной железы определялись методом интраоперационной пульсографии по 3.М. Сигалу по отсутствию пульса. Последнее удалили. Полости дренировали.

Рассекали большие сальники на две неравные части по длине ближе к левому краю (рис. 1), тщательно укрывали поджелудочную железу левым краем большого сальника и фиксировали его к перипанкреотической клетчатке П-образными кетгутовыми швами (рис. 2). После окутывания поджелудочной железы частью большого сальника снимали пульсограмму поджелудочной железы.

Оставшуюся часть $2 / 3$ большого сальника накладывали на печень и фиксировали его отдельными кетгутовыми швами (рис. 3). Брюшная полость ушивалась наглухо.

Животные медикаментозного лечения не получали. 5 животных повторно прооперированы через 3 суток, оставшиеся 5 - через 10 дней. Проведено гистологическое исследование поджелудочной железы. 


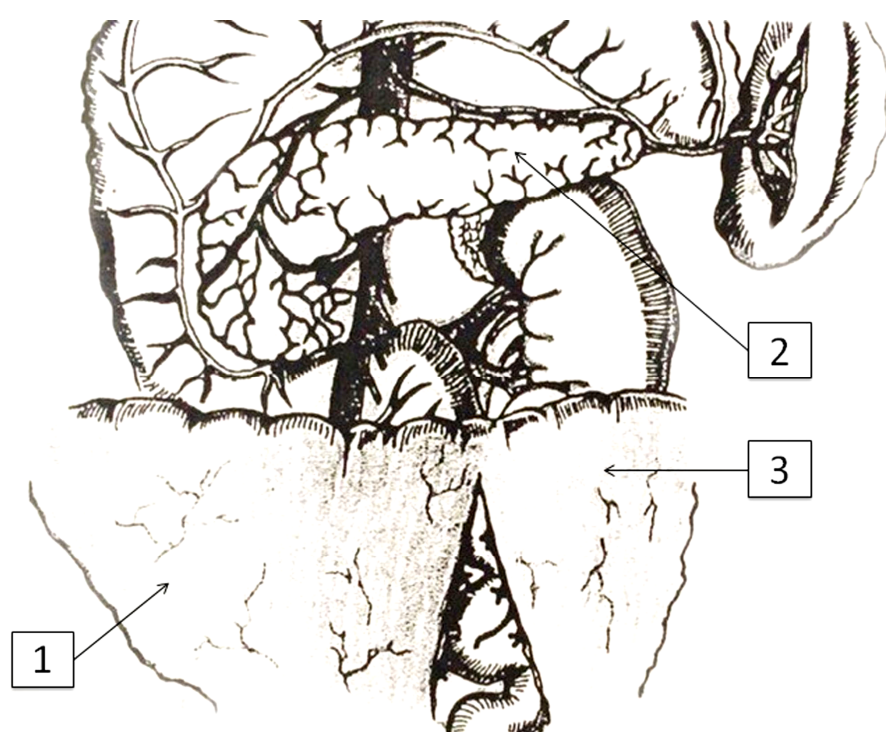

Рис. 1. Большой сальник рассечен на две неравные части, ближе к левому краю. 1 - правый край большого сальника, 2 - поджелудочная железа, 3 - левый край большого сальника.

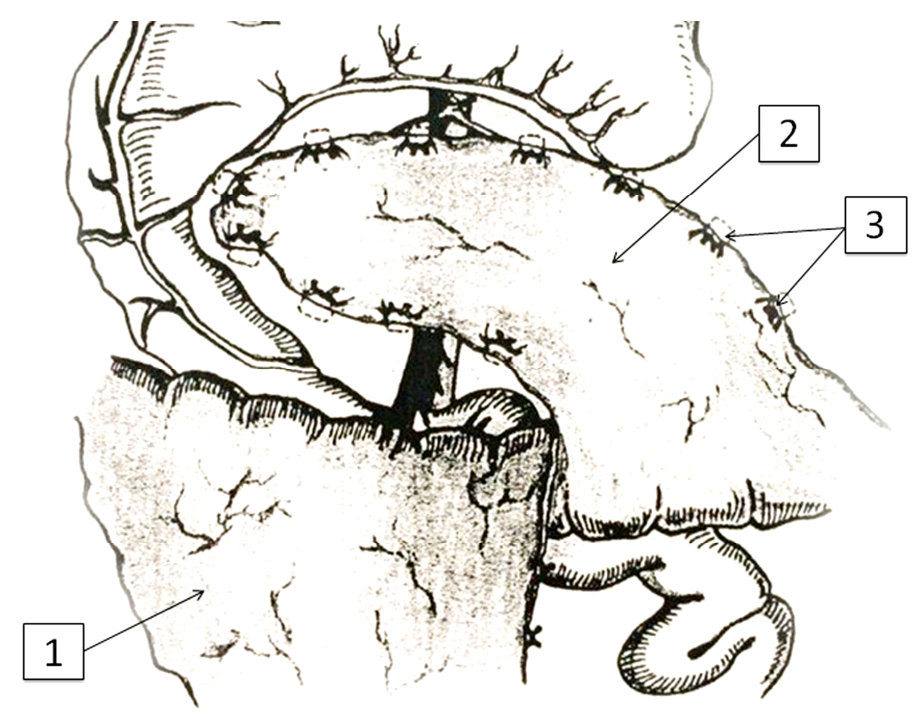

Рис. 2. Поджелудочная железа покрыта левым краем большого сальника. Сальник фиксирован к перипанкреатической клетчатке П-образными швами. 1 - правый край большого сальника, 2 - П-образные швы, 3 - левый край большого сальника.

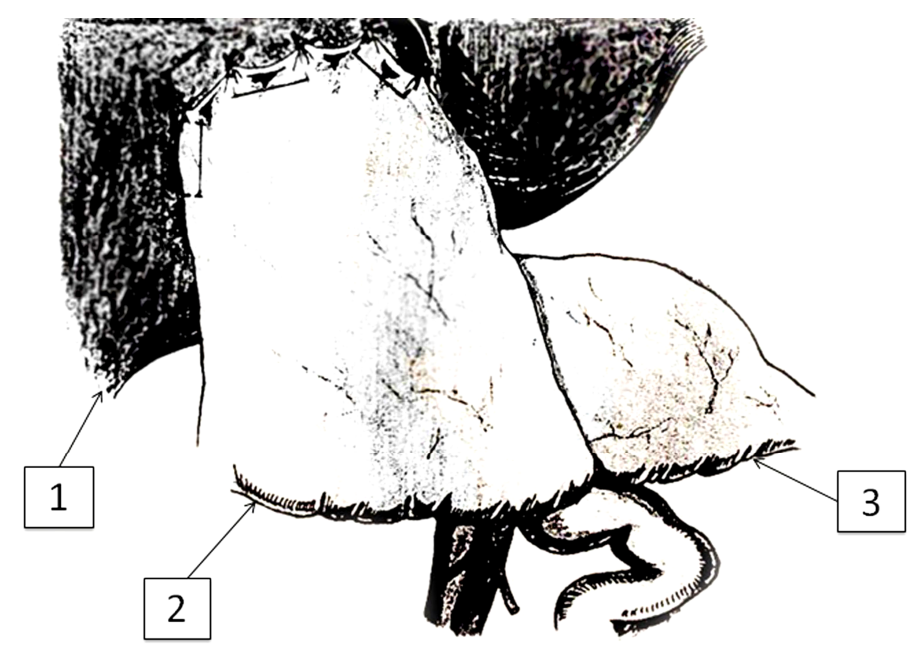

Рис. 3. Подшивание края большого сальника к правой доле печени. 1 - правая доля печени, 2 - край большого сальника, 3 - левый край сальника. 


\section{РЕЗУЛЬТАТЫ ИССЛЕДОВАНИЯ И ИХ ОБСУЖДЕНИЕ}

АПО здоровой поджелудочной железы в среднем составила 2,0 $\pm 0,3$ мм. АПО при остром панкреатите через 3-е суток после операции составила в среднем $0,9 \pm 0,2$ мм (рис. 4).

После окутывания поджелудочной железы левым краем большого сальника АПО в среднем составила $1,2 \pm 0,2$ мм (рис. 5, табл. 1).

При гистологическом исследовании (окраска гематоксилин-эозином) поджелудочной железы через 3-е суток: дезагрегация секреторных отделов, инфильтрация паренхимы и стромы лейкоцитами, сужение артериол, расширение вен; пристеночное стояние эритроцитов, агрегация форменных элементов, набухание эндотелиальных клеток, расширение межклеточных пространств.

Эксперементальные исследования позволили перейти к операции на больных [9].

Больной X. Диагноз: геморрагический асептический панкреонекроз, ферментативный перитонит, алкогольный гепатит.
Операция: лапаротомия, интраоперационный гемодинамический контроль, некрэктомия поджелудочной железы, панкреатооментопексия, гепатооментопексия, санация, дренирование брюшной полости.

При ревизии органов брюшной полости в малом тазу и в подпеченочном пространстве обнаружено до 1500 мл серозно-геморрагической жидкости. Последняя удалена электроотсосом.

На большом сальнике местами располагаются стеариновые пятна. Желчные пути без особенностей. Печень увеличена, плотноватой консистенции. Вскрыта сальниковая сумка, поджелудочная железа резко отечна, уплотнена, темно-вишневого цвета на всем протяжении. На передней поверхности поджелудочной железы обнаружены три очага некроза неправильной формы: 2,0х1,0 см; 3,0х2,0 см; 3,0х2,05 см. Амплитуда пульсовых осцилляций некротических участков отсутствует. Очаги удалены методом дигитоклазии, полости дренированы.

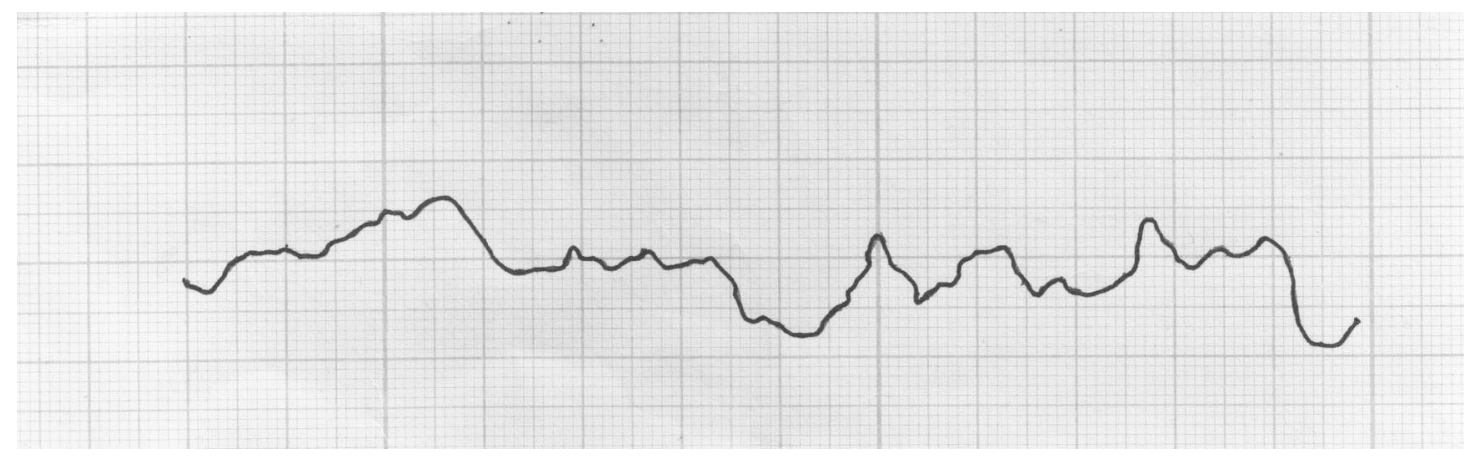

Рис. 4. Пульсограмма при моделированном остром панкреатите. Снижение АПО через 3 суток.

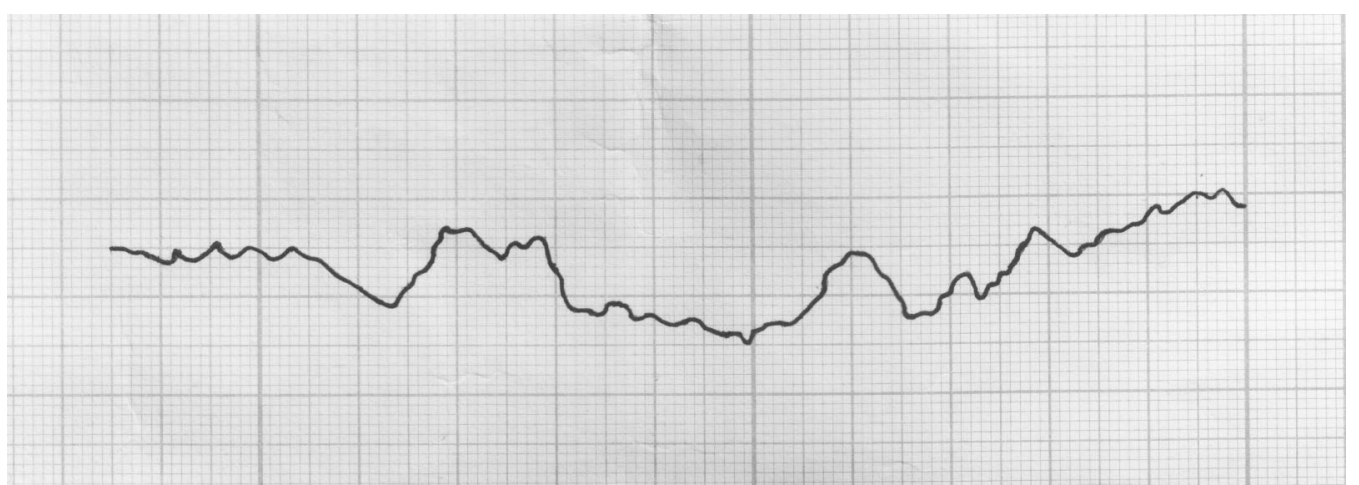

Рис. 5. Пульсограмма после укрытия поджелудочной железы левым краем большого сальника. АПО имеет положительную динамику.

Таблица 1

Показатели динамики АПО при моделировании асептического панкреатита

\begin{tabular}{|l|c|}
\hline \multicolumn{1}{|c|}{ Отделы } & Амплитуда пульсовых осцилляций (мм) \\
\hline Интактная поджелудочная железа & $2,0 \pm 0,3$ \\
\hline Через 3 суток после операции & $0,9 \pm 0,2$ \\
\hline После оментопексии & $1,2 \pm 0,2$ \\
\hline
\end{tabular}


Большой сальник продольно рассечен на два неравных лоскута ближе к левому краю до основания. При гемодинамическом исследовании 1/3 левого края большого сальника выявлена амплитуда пульсовых осцилляций 4,5 мм, $2 / 3$ правого края укрыты левым лоскутом большого сальника; произведена фиксация его П-образными кетгутовыми швами к перипанкреатической клетчатке. Правый лоскут 2/3 большого сальника подшит П-образными кетгутовыми швами к правой доле печени. Послеоперационный период протекал без осложнений. Больной обследован через 5 лет. Состояние удовлетворительное, жалоб не предъявляет. Биомеханические анализы крови и мочи без патологии.

В настоящее время существуют нерешенные задачи как по тактическим вопросам, так и по выбору оптимального метода лечения больных острым деструктивным панкреатитом, которые должны решаться на основании использования современных технологий в хирургии и реаниматологии.

Показанием к лапаротомному вмешательству при стерильном панкреонекрозе считают сохранение или прогрессирование полиорганной недостаточности, несмотря на проведение интенсивной консервативной терапии, лапароскопической санации и дренирования брюшной полости и/или чрезкожных операций, выполняемых под ультразвуковым или КТ контролем.

Как показали исследования, укрытие поджелудочной железы участком сальника с удовлетворительным кровоснабжением ведет к увеличению средних показателей АПО с $0,9 \pm 0,2$ мм до $1,2 \pm$ 0,2 мм и позволяет определить некротические участки по 3.М. Сигалу и дренировать их.

Использование данного способа хирургического лечения асептического панкреонекроза позволило определять и удалять некротические участки поджелудочной железы, улучшить кровоснабжение поджелудочной железы и печени за счет использования сосудов большого сальника с удовлетворительным АПО и высокой сатурацией (78-96\%), тем самым остановить прогрессирование заболевания, предупредить рецидивы и переход в хроническую форму.

Для определения наиболее высоких показателей сатурации и кровоснабжения участка большого сальника необходимо обеспечить хирургические отделения городских и районных центральных больниц оксигемометром и аппаратом 3.М. Сигала.

\section{ЛИТЕРАТУРА}

1. Акрамов Э.Х., Акылбеков И.К., Бородин Ю.И., Любарский М.С. Избранные вопросы гнойной хирургии. - Бишкек-Новосибирск : НЦРВХ МЗ KР, 2007. $-644 \mathrm{c}$.

2. Брискин Б.С. Поражение печени при остром панкреатите, выбор и обоснование экстракорпоральной детоксикации // Научно-практический журнал «Анналы хирургической гепатологии». 2008. - № 3. - С. 20.

3. Брискин Б.С. Профилактика и лечение гнойнонекротических осложнений панкреонекроза // Российский журнал гастроэнтерологии, гепатологии, колопроктологии - 2005. - Т. 15, № 1. - С. 50-58.

4. Дюжева Т.Г., Гальперин Э.И., Чевокин А.Ю., Докучаев К.В., Ахаладзе Г.Г., Погосян Г.С., АбдельГалил Р. Диагностика и хирургическое лечение панкреонекроза // Хирургия. - 2003. - № 3. C. 55-59.

5. Заривчатский М.Ф., Блинов С.А. Острый панкреатит. - Пермь, 2002. - 103 с.

6. Пушкарев В.П., Лекомиеев Б.А. Лечение панкреонекроза и его осложнений // Вятский медицинский вестник. - 2006. - № 2. - С. 134-135.

7. Савельев В.С. Варианты течения панкреонекроза, определяющие выбор оптимальной тактики хирургического лечения // Анналы хирургии. 2006. - № 1. - C. 40.

8. Сигал 3.М., Вальтер Э.О. Хирургическая тактика при остром панкреатите // Ижевск : Удмуртия, 1990. - С. 272.

9. Способ хирургического лечения асептического панкреонекроза: заявка 2012133621/14 Российская Федерация, МПК А61В 17/00 / Сигал 3.М. № 2557417; заявлено 06.08.2012; опубл. 20.07.2015, Бюл. № 5. - 7 c.

10. Buchler M. Acute pancreatic: diagnosis and terapy // Amr. Surg. - 2000. - Vol. 232. - P. 175-180.

11. Cuschieri A. Laparoscopic hand-assisted hepatic surgery // Semin Laparosc Surg - 2001. - Vol. 8, N 2 - P. 104-113.

12. De Campos T., Cerqueira C., Kuryura L., Parreira J.G., Soldá S., Perlingeiro J.A., Assef J.C., Rasslan $S$. Morbimortality indicatorys in severe acute pancreatis // JOP. J Pancreas. - 2008. - Vol. 9, N 6. P. 690-697.

13. Heinrich S., Schafer M., Rousson V., Clavien P.A. Evidence-based treatment of acute pancreatitis: a look at established paradigms // Ann Surg. - 2006. Vol. 243 - P. 154-168.

14. Johnston C.D., Imrie C.W. Pancreatic disease: basic science and clinical management. - London : Springer-Verlag, 2004. - P. 383-399.

15. Kingham T.P., Shamamian P. Management and spectrum of complications in patients undergoing surgical debridement for pancreatic necrosis // Am. Surg. - 2008. - Vol. 74. - P. 1050-1056. 